\title{
Morphometrical Analysis of the Effect of Nicotine Administration on Brain's Prefrontal Region in Male Rat
}

\author{
Análisis Morfométrico del Efecto de la Administración de Nicotina \\ sobre la Región Prefrontal del Cerebro en Rata Macho
}

Jalili, C.*; Salahshoor, M. R.*; Khademi, F.**; Jalili, P.*** \& Roshankhah, S. H.*

JALILI, C.; SALAHSHOOR, M. R.; KHADEMI, F.; JALILI, P. \& ROSHANKHAH, S. H. Morphometrical analysis of the effect of nicotine administration on brain's prefrontal region in male rat. Int. J. Morphol., 32(3):761-766, 2014.

SUMMARY: Nicotine is the most important alkaloid compound in tobacco. One of the major effects of nicotine is stimulation of mesocorticolimbic system. Prefrontal cortex plays a pivotal role in personality and mental state. It is considered the main cause of addiction as it is located in mesocorticolimbic dopamine system. Twenty four male rats were divided into four groups based on nicotine administration dose $(0,0.5,1$ and $1.5 \mathrm{~g} / \mathrm{kg})$. After animals were anesthetized, their brains were fixed using transcardiac method. Tissue processing and Golgi staining were performed and the stained tissue sections were analyzed by optic microscope and Motic software. By increasing the dose, nicotine significantly decreased the number of neuronal processes. In the higher dose, nicotine caused a significant decrease and increase in the size of pericarions and dendritic spines, respectively $(\mathrm{p}<0.05)$. Nicotine administration can decrease the size of pericarion and number of dendritic spines in the prefrontal cortex.

KEY WORDS: Morphometric; Prefrontal cortex; Nicotine, Rat.

\section{INTRODUCTION}

Around $30 \%$ of the people in different countries are addicted to nicotine. Nicotine is also the leading cause of smoking. There are about 3500 different substances in the particulate phase of tobacco smoke, the most important of which is nicotine (Mizrak et al., 2012). Nicotine is an alkaloid which is found in tobacco plant and belongs to the Solanaceae family (Hritul et al., 2013). Stimulation of nicotine receptors causes an increase in acetylcholine release in the brain (Mousa et al., 2013). It seems that some of the effects of nicotine are due to the ability of this substance in releasing different neurotransmitters (Uchida et al., 2013).

Nicotine makes dopamine release from dopaminergic neurons, limbic system and ventral tegmental area. Dopaminergic pathway is suggested to be the most important path for nicotine function (Li et al., 2013). Mesocorticolimbic dopamine pathway is the major cause of drug-dependent addictive behaviors. Dopaminergic system plays a vital role in controlling oscillatory motions, cognition, memory and especially reward behaviors. Nicotine acetylcholine receptors are found in pathways such as ventral tegmental and accumbens nucleus. Stimulation of these receptors increases dopamine release in accumbens nucleus, amygdala, hippocampus and prefrontal cortex and induces feeling of joy in the consumer (Millar \& Gotti, 2009). As prescription of addictive drugs can lead to behavioral changes, morphometric changes of neurons seem possible. Thus, numerous studies have investigated the effects of addictive drugs on the morphological changes in neurons present in different parts of dopamine mesolimbic system. Nicotine administration in animals can increase the dendrite length of pyramidal neurons in the basal part of pyramidal cells existing in medial frontal cortex (Bergstrom et al., 2008). It can also decrease the size of pyramidal cells in hippocampus CA1 area. The prefrontal cortex of brain plays a pivotal role in personality and mental state. The reason for analyzing the prefrontal region is because of the function this cortex has in controlling behavior, judgment and anticipation (Moon et al., 2002). Many studies have examined the effects of addictive drugs on morphological changes in neurons in different parts of dopamine mesolimbic system. However, with regard to the significant role of prefrontal cortex, no study has been conducted on the effects of nicotine on morphological changes in prefrontal cortex region, so far.

Fertility and Infertility Research Center, Kermanshah University of Medical Sciences, Kermanshah, Iran.

** Student of MSc., Kermanshah University of Medical Sciences, Kermanshah, Iran.

${ }^{* * * *}$ Student of MD, Fertility and Infertility Research Center, Kermanshah University of Medical Sciences, Kermanshah, Iran. 


\section{MATERIAL AND METHOD}

Experimental animals. Twenty four Wistar male rats with the mean weight of 220-250 g were purchased from IranPasteur Institute. One week before the experiment, the animals were kept in the animal house under the laboratory conditions, temperature of $22 \pm 2^{\circ} \mathrm{C}$ and 12 hours dark/light cycle with free access to water and food in order to adapt to the environment. The ethical guidelines of working with animals were taken into account during the study period (Rasia-Filho et al., 2000).

Nicotine structure. Nicotine was purchased from Sigma (C6499, USA). Chemical name: 1-Metyl-2-3-pyridelPirolidin. Chemical formula: C10H14N2. Half-life of 2 hours. Metabolism: hepatic. Molar mass: $162.23 \mathrm{~g} / \mathrm{mol}$ IUPC name: S-3-1-(1-Methyl-2-Pyrrolidinyl) Pyridine (Fig. 1).
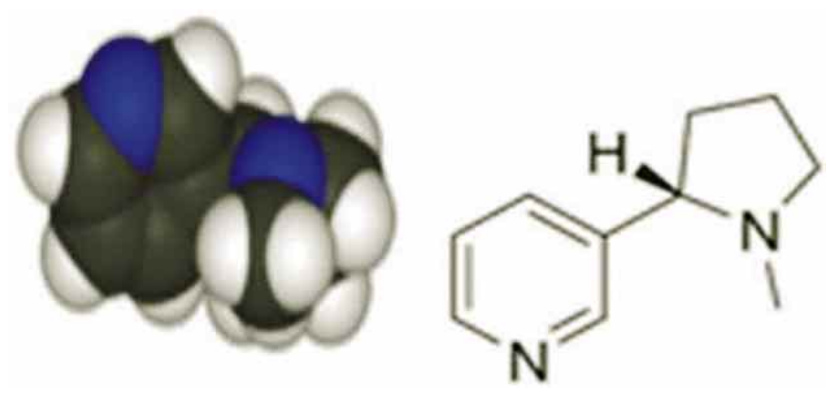

Fig. 1. Nicotine structure.

Animal classification. The animals were randomly assigned to four groups $(\mathrm{n}=6)$. Different doses of nicotine $(0,1.5,0$ and $1.5 \mathrm{mg} / \mathrm{kg}$ ) were administered to various groups intraperitoneally. The final administration was $1 \mathrm{mg} / \mathrm{kg}$ in all cases (Biala \& Weglinska, 2004).

Method and stages of nicotine administration to animals. Given that administration of nicotine dose is deadly, the following steps were therefore taken to avoid nicotine toxicity: Nicotine $(0.4 \mathrm{mg} / \mathrm{kg})$ was administered to animals in specific times for three consequent days. Then, the nicotine dose was increased and experimental groups received $0.5,1$ and $1.5 \mathrm{mg} / \mathrm{kg}$ nicotine solution, respectively. The animals in the fourth group, however, received equal amounts of normal saline intraperitoneally at the same time, and nicotine administration was continued for the following three days (Biala \& Weglinska, 2004).

Transcardiac perfusion. For rapid and constant fixation, tissue fixation was performed through perfusion. The animals were anesthetized with ketamine $(70 \mathrm{mg} / \mathrm{kg}) 12$ hours after the last nicotine administration. The thorax wall was opened from the middle line and after thoracotomy was completed, the left ventricular apex was perforated and a glass cannula with $1 \mathrm{~mm}$ diameter was inserted in it and was fixed in the ascending aorta. Pericardium and right auricle were cut and the descending aorta was clamped right above diaphragm. Perfusion was first performed with $200 \mathrm{ml} \mathrm{0.9 \%}$ saline and then with $1000 \mathrm{ml}$ fixative solution (formaldehyde buffer) (fixative solution should be $200-300 \mathrm{ml}$, equal to the animal blood volume, and should be administered $20 \mathrm{ml}$ per minute) (Katzman, 1961).

Golgi staining.Golgi method is a major technique to observe dendrites and dendritic spines. The whole brain perfusion was carried out for 2-3 days. Slices were delivered to 100 $\mathrm{ml} 3.5 \%$ potassium dichromate and placed in the room temperature and darkness for 5-7 days. Having been washed in $0.75 \%$ silvernitrate, issue sections were placed in the room temperature and darkness for 2-3 days. Washing was done with distilled water several times for half an hour and dehydration was carried out in acetone or ethanol for 2 hours. After dehydration, clearing in xylene, embedding and preparing $100-200 \mu$ sections, the sections were mounted on the chambers (Gibb \& Kolb, 1998).

Measurement of neuronal parameters. The number of neuronal processes and dendritic spines, and size of pericarion were analyzed by Motic and IT Image Tool (version 3) software. Random counting method (the number of spines in five $2 ¥ 2 \mathrm{~cm}$ squares in an area of $10 ¥ 10 \mathrm{~cm}$ in images with 400x magnification) was used to analyze the number of dendritic spines (Karpova et al., 2005).

Data analysis. One-way analysis of variance (ANOVA) and Tukey tests were used to perform the statistical analysis of experimental groups compared to control group.

\section{RESULTS}

Pericarions' size. The results indicated that, by increasing the dose of nicotine $(0.5 \mathrm{mg} / \mathrm{kg}, 1 \mathrm{mg} / \mathrm{kg}, 1.5 \mathrm{mg} /$ $\mathrm{kg}$ ), the size of pericarions decreased, which was only significant for $1.5 \mathrm{mg} / \mathrm{kg}$ dose $(\mathrm{p}<0.05)$ (Fig. 2).

Number of neuronal processes. The findings revealed that the number of neuronal spines decreased significantly by increasing the nicotine dose $(\mathrm{p}<0.001)$ (Fig. 3 ).

Measurement of dendritic spines. The results showed that, by increasing nicotine dose $(0.5 \mathrm{mg} / \mathrm{kg}, 1 \mathrm{mg} / \mathrm{kg}, 1.5 \mathrm{mg} / \mathrm{kg})$, the number of dendritic spines increased. This increase was merely reported significant for $1.5 \mathrm{mg} / \mathrm{kg}$ dose ( $\mathrm{p}<0.05)$ (Fig. 4). 

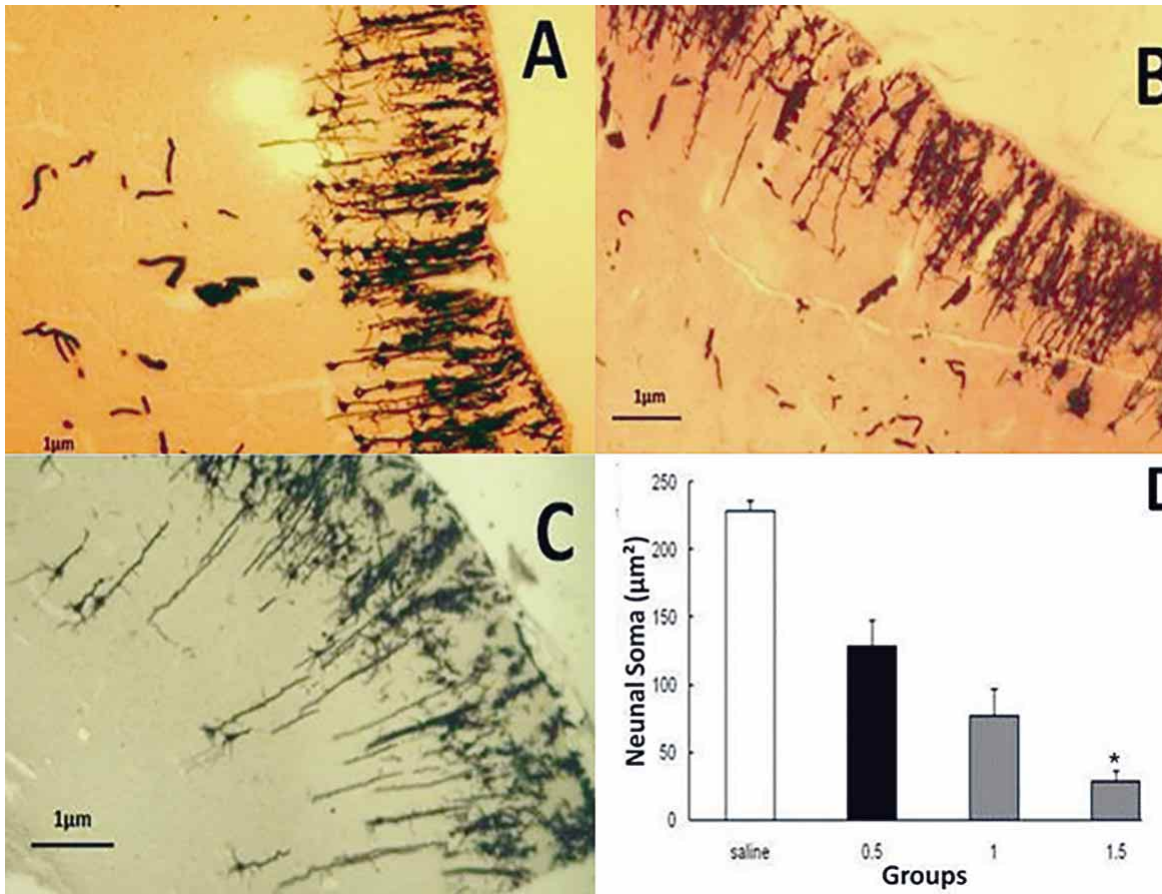

Fig. 2. Effect of different doses of nicotine on the number of neurons in prefrontal region in male rats. (A-D). *(p<0.05). A. Saline. B. Nicotine $0.5 \mathrm{mg} / \mathrm{kg}$. C. Nicotine $1.5 \mathrm{mg} / \mathrm{kg}$ (Magnification 100X).
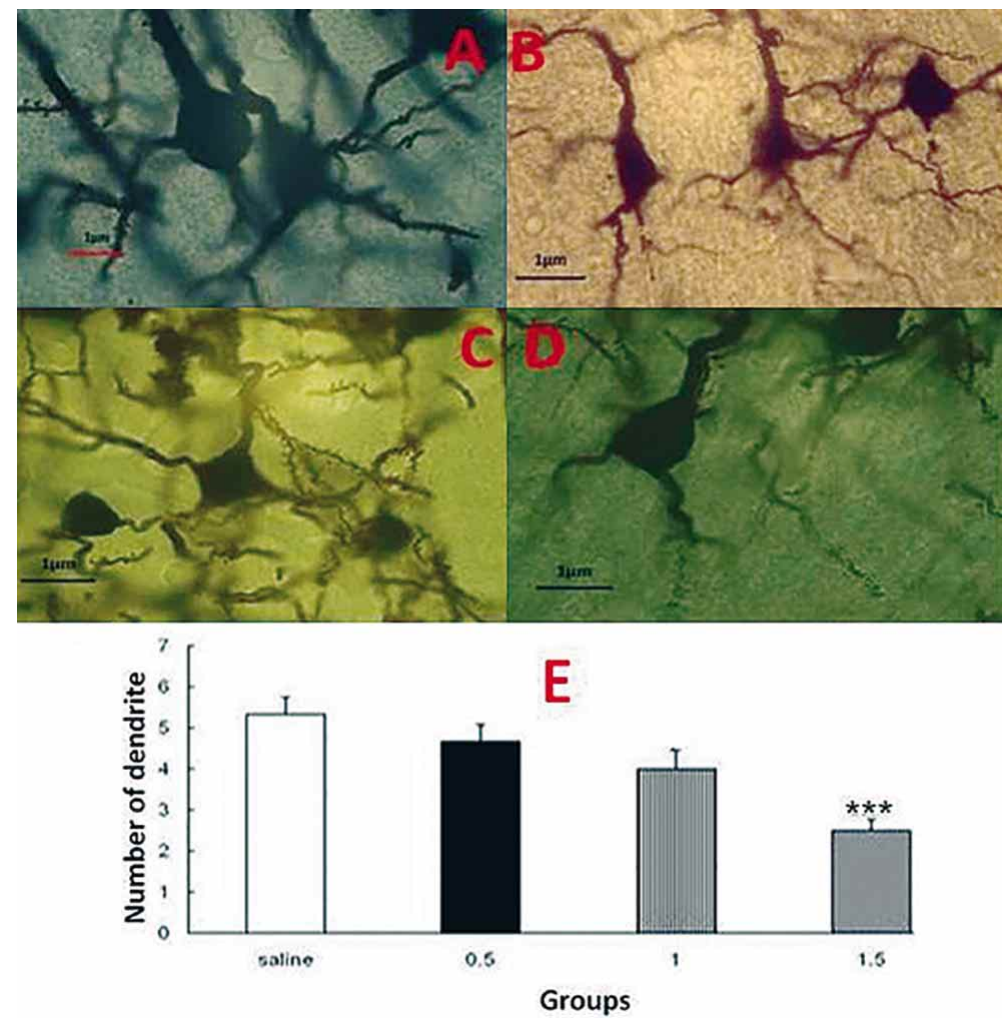

Fig. 3. Effect of different doses of nicotine on the number of neuronal processes in prefrontal region in male rats. (A-E). *** $(\mathrm{p}<0.001)$.A: Saline. B: Nicotine $0.5 \mathrm{mg} / \mathrm{kg}$. C: Nicotine $1 \mathrm{mg} / \mathrm{kg}$. D: Nicotine $1.5 \mathrm{mg} / \mathrm{kg}$ (Magnification100X). 
The results showed that, by increasing nicotine dose $(0.5 \mathrm{mg} / \mathrm{kg}, 1$ $\mathrm{mg} / \mathrm{kg}, 1.5 \mathrm{mg} / \mathrm{kg}$ ), the number of dendritic spines increased. This increase was merely reported significant for $1.5 \mathrm{mg} / \mathrm{kg}$ dose $(\mathrm{p}<0.001)$ (Fig. 4).
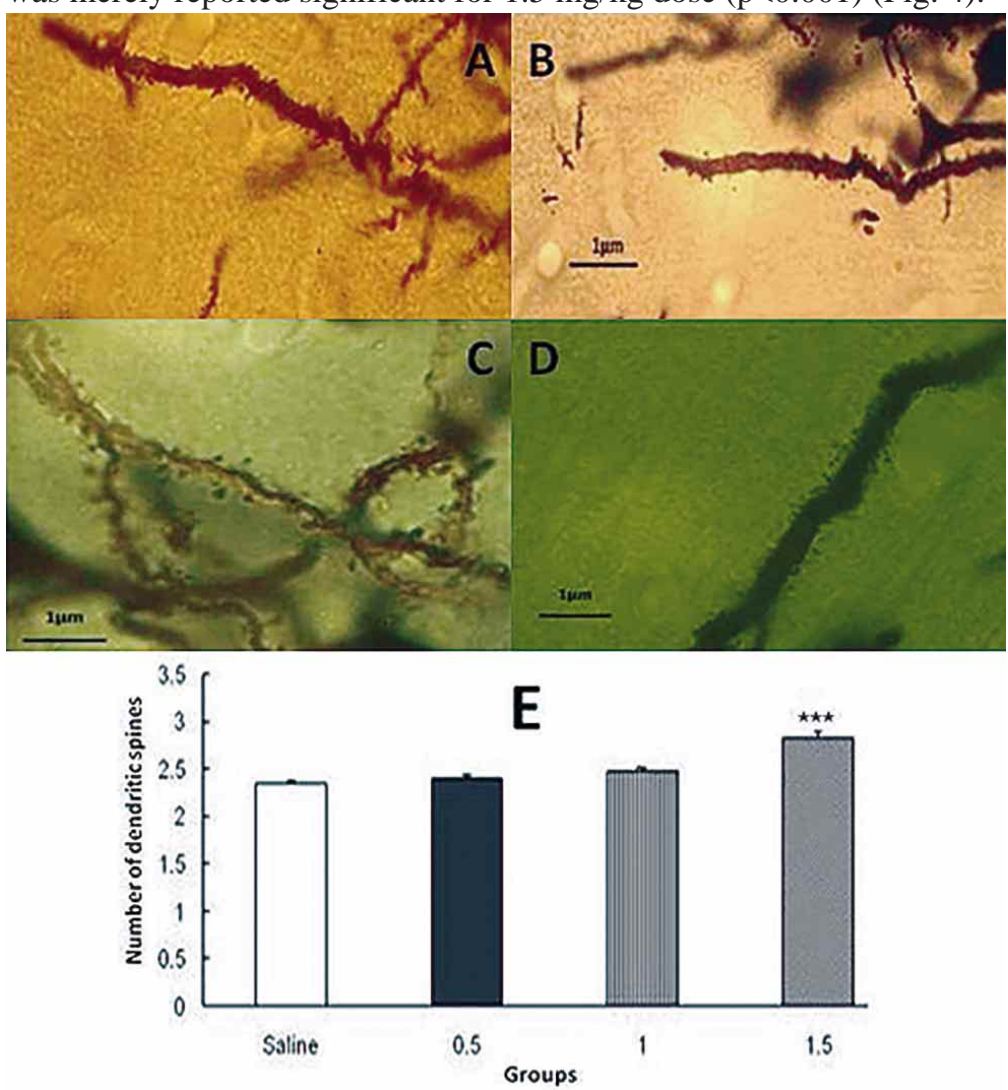

Fig. 4. Effect of different doses of nicotine on the number of neuronal processes in prefrontal region in male rats. (A-E) *** $(\mathrm{p}<0.001)$. A. Saline. B. Nicotine 0.5 $\mathrm{mg} / \mathrm{kg}$. C. Nicotine $1 \mathrm{mg} / \mathrm{kg}$. D. Nicotine $1.5 \mathrm{mg} / \mathrm{kg}$ (Magnification100X).

\section{DISCUSSION}

The findings of the present study indicated that administration of different doses of nicotine, as a drug, affected neuronal parameters and significantly decreased dendritic spines. It seems that the abovementioned effects are partly associated with increasing lipidoxidase production due to nicotine administration, which may cause irreversible damage to the structure of cell membrane in neurons (Mullane et al., 1984). Also, the obtained results can indicate the disruptive effects of nicotine on dopaminergic system, part of which is prefrontal cortex (Mansour et al., 1994). The findings of the present research confirmed the results of the study by Jalili et al. (2009), in which they demonstrated that nicotine administration led to morphological changes in neurons in the hippocampal CA1 region in male rat, which included decrease of cells count and pyramidal cells processes in comparison with control group. However, the results of this study are in contrast with the findings of (Vega et al., 2004) study that reported an increase for the dendritic branches of 1-4th layers of the inner prefrontal cortex due to hypertension. Moreover, the findings of the present study revealed a decrease in the size of pericarions as a result of nicotine in lower doses as well, but this decrease was significant only in the higher dose $(1.5 \mathrm{mg} / \mathrm{kg})$. It seems that these results are associated with the mechanisms of reducing nicotine metabolism in brain and some other parts of the body. This damage can be accompanied with memory disorder, including delay in spatial information (Wilson et al.,1993).

The obtained results, however, were in contrast with the findings of (Haung et al., 2007) that indicated chronic administration of morphine via subcutaneous injection could decrease the size of cell body of dopamine cells in ventral tegmental area by about $25 \%$. In addition, the results of this study showed that various doses of nicotine increased the number of dendritic spines. Dendritic spines are membrane ridges on the neuron surface. Spines consist of a head (0.001-1 $\left.\mathrm{m}^{3}\right)$ which is connected to neuron by a thin neck with $0.1 \mu \mathrm{m}$ diameter (Coss et al., 1980) Given that dendritic spines play the major part in synaptic transmission, it is no wonder that most of the disease states are associated with changes in morphology and density of dendritic spines. It seems that dendritic spines connect axones and dendrites and are involved in the formation of memory. The results of this part may be due to the effects of nicotine in the electrical stimulation of brain in different regions. The results obtained are compatible with those of the study conducted by Brown et al. (2001) in which they reported nicotine increased the dendrite length and spine density in accumbens nucleus and singulate cortex. The patients suffering from traumas in the prefrontal cortex lose social awareness, ability to talk, judgment and initiative, and emotional and peronality reactions change remarkably in them so that they would hardly be able to live. Based on the results of this study, it can be generally argued that nicotine has destructive effects on the prefrontal cortex of brain.

\section{ACKNOWLEDGEMENTS}

This study was approved and financially supported by the Fertility and Infertility Research Center, Kermanshah University of Medical Sciences. There is no conflict of interest in this study. 
JALILI, C.; SALAHSHOOR, M. R.; KHADEMI, F.; JALILI, P. \& ROSHANKHAH, S. H. Análisis morfométrico del efecto de la administración de nicotina sobre la región prefrontal del cerebro en rata macho. Int. J. Morphol., 32(3):761-766, 2014.

RESUMEN: La nicotina es el compuesto alcaloide más importante del tabaco. Uno de sus principales efectos es la estimulación del sistema mesocorticolímbico. La corteza prefrontal desempeña un papel fundamental en la personalidad y estado mental. Esta es considerada la principal causa de la adicción, ya que se encuentra en el sistema mesocorticolímbico dopaminérgico. Veinticuatro ratas macho fueron divididas en cuatro grupos basados en la dosis de administración de nicotina $(0,0,5,1$ y $1,5 \mathrm{~g} / \mathrm{kg})$. Luego fueron anestesiados y sus cerebros se fijaron mediante perfusión transcardíaca. Se realizó el procesamiento de tejidos y las secciones bajo tinción de Golgi fueron analizadas mediante microscopia óptica y el software Motic. Con el aumento de dosis, la nicotina redujo significativamente el número de procesos neuronales. En la dosis más alta, la nicotina causó una disminución y aumento significativo en el tamaño de pericarion y espinas dendríticas, respectivamente $(\mathrm{p}<0,05)$. La administración de nicotina puede disminuir el tamaño del pericarion y el número de espinas dendríticas en la corteza prefrontal.

\section{PALABRAS CLAVE: Morfométrico; Corteza prefrontal; Nicotina; Rata.}

\section{REFERENCES}

Bergstrom, H. C.; McDonald, C. G.; French, H. T. \& Smith, R. F. Continuous nicotine administration produces selective, agedependent structural alteration of pyramidal neurons from prelimbic cortex. Synapse, 62(1):31-9, 2008.

Biala, G. \& Weglinska, B. Calcium channel antagonists attenuate cross-sensitization to the rewarding and/or locomotor effects of nicotine, morphine and MK-801. J. Pharm. Pharmacol., 56(8):1021-8, 2004.

Brown, R. W. \& Kolb, B. Nicotine sensitization increases dendritic length and spine density in the nucleus accumbens and cingulate cortex. Brain Res., 899(1-2):94-100, 2001.

Coss, R. G.; Brandon, J. G. \& Globus, A. Changes in morphology of dendritic spines on honeybee calycal interneurons associated with cumulative nursing and foraging experiences. Brain Res., 192(1):49-59,1980.

Gibb, R. \& Kolb, B. A method for vibratome sectioning of GolgiCox stained whole rat brain. J. Neurosci. Methods, 79(1):1-4, 1998.

Hritcu, L.; Stefan, M.; Brandsch, R. \& Mihasan, M. 6-hydroxy-Lnicotine from Arthrobacter nicotinovorans sustain spatial memory formation by decreasing brain oxidative stress in rats. J. Physiol. Biochem., 69(1):25-34, 2013.

Huang, L. Z.; Abbott, L. C. \& Winzer-Serhan, U. H. Effects of chronic neonatal nicotine exposure on nicotinic acetylcholine receptor binding, cell death and morphology in hippocampus and cerebellum. Neuroscience, 146(4):1854-68, 2007.

Jalili, C.; Sadeghi, Y. \& Sahraei, H. Morphological changes in hippocampus CA1 neurons after nicotine in rats. Behbood, 13(1):1-9, 2009.
Katzman, R. Electrolyte distribution in mammalian central nervous system. Are glia high sodium cells? Neurology, 11:27-36,1961.

Karpova, A. V.; Bikbaev, A. F.; Coenen, A. M. \& van Luijtelaar, G. Morphometric Golgi study of cortical locations in WAG/Rij rats: the cortical focus theory. Neurosci. Res., 51(2):119-28, 2005 .

Li, F.; Chen, Z.; Pan, Q.; Fu, S.; Lin, F.; Ren, H.; Han, H.; Billiar, T. R.; Sun, F. \& Li, Q. The protective effect of PNU-282987, a selective a7 nicotinic acetylcholine receptor agonist, on the hepatic ischemia-reperfusion injury is associated with the inhibition of high-mobility group box 1 protein expression and nuclear factor kB activation in mice. Shock, 39(2):197-203, 2013.

Mansour, A.; Fox, C. A.; Burke, S.; Meng, F.; Thompson, R. C.; Akil, H. \& Watson, S. J. Mu, delta, and kappa opioid receptor mRNA expression in the rat CNS: an in situ hybridization study. J. Comp. Neurol., 350(3):412-38, 1994.

Millar, N. S. \& Gotti, C. Diversity of vertebrate nicotinic acetylcholine receptors. Neuropharmacology, 56(1):237-46, 2009.

Mizrak, S.; Turan, V.; Terek, M. C \& Ercan, G. The effect of long term nicotine exposure on nicotine addiction and fetal growth. J. Turk. Ger. Gynecol. Assoc., 13(4):237-41, 2012.

Moon, J. S.; Kim, J. J.; Chang, I. Y.; Chung, Y. Y.; Jun, J. Y.; You, H. J. \& Yoon, S. P. Postnatal development of parvalbumin and calbindin D-28k immunoreactivities in the canine anterior cingulate cortex: transient expression in layer V pyramidal cells. Int. J. Dev. Neurosc., 20(6):511, 2002. 
Mousa, S. A.; Arias, H. R. \& Davis, P. J. Role of Non-neuronal Nicotinic Acetylcholine Receptors in Angiogenesis Modulation. In: Mousa, S. A. \& Davis, P.J. (Eds.). Angiogenesis Modulations in Health and Disease. New York, Springer, 2013. pp.55-75.

Mullane, K. M.; Read, N.; Salmon, J. A. \& Moncada, S. Role of leukocytes in acute myocardial infarction in anesthetized dogs: relationship to myocardial salvage by anti-inflammatory drugs. J. Pharmacol. Exp. Ther., 228(2):510-22, 1984.

Rasia-Filho, A. A.; Londero, R. G. \& Achaval, M. Functional activities of the amygdala: an overview. J. Psychiatry Neurosci., 25(1):14-23, 2000.

Uchida, S.; Hotta, H.; Misawa, H. \& Kavashima, K. The missing link between long-term stimulation of nicotinic receptors and the increases of acetylcholine release and vasodilation in the cerebral cortex of aged rats. J. Physiol. Sci., 63(2):95-101, 2013.

Vega, E.; Gómez-Villalobos, M. J. \& Flores, G. Alteration in dendritic morphology of pyramidal neurons from the prefrontal cortex of rats with renovascular hypertension. Brain Res., 1021(1):112-8, 2004.

Wilson, F. A.; Scalaidhe, S. P. \& Goldman-Rakic, P. S. Dissociation of object and spatial processing domains in primate prefrontal cortex. Science, 260(5116):1955-8, 1993.
Correspondence to:

Dr. Mohammad Reza. Salahshoor

Fertility and Infertility Research Center

Kermanshah University of Medical Sciences

Kermanshah

IRAN

Email: reza.salahshoor@yahoo.com

Received: 29-07-2013

Accepted: 12-05-2014 